F.G. King MD FRCP(C),

A. D. Baxter BM BCH FFARCS FRCP(C), G. Mathieson MB CH в MSC FRCP(C)

\title{
Tissue reaction of morphine applied to the epidural space of dogs
}

Epidural morphine has found increasing popularity in clinical trials for the relief of chronic and postoperative pain relief. This study was conducted to determine if there was any adverse tissue reaction when morphine was applied to the epidural space of dogs. Sixteen dogs

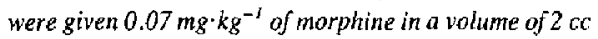
of normal saline into the epidurat space. Gross and microscopic studies of the epidural space, durs, and spinal cord did not show any adverse tissue reaction.

\section{Key words}

ANAESTHETIC TECHNIQUES, EPIDURAL: epidUral morphine, tissue reaction.

Recent studies have demonstrated the analgesic effects of morphine applied to the spinal subarachnoid space ${ }^{1,2}$ and the epidural space. ${ }^{3,4}$ There is good experimental evidence implicating the spinal cord as a probable site of action of narcotic analgesics. ${ }^{5,6}$ Pert $^{7}$ and his group have autoradiographically shown opiate receptors to be localized in the substantia gelatinosa of the spinal cord.

Epidural morphine has found increasing popularity in clinical trials for the relief of chronic and post-operative pain. ${ }^{2,8-10.15}$ Numerous reports on this relatively new technique confirm that morphine applied to the epidural space appears to be an

From the Department of Anaestheșia, Health Sciences Centre, Department of Pathology (Dr. Mathieson), Memorial University of Newfoundland, St. John's, Newfoundland.

Address correspondence to: Dr. F.G. King, Department of Anacsthesia, Faculty of Medicine, Memorial University of Newfoundland, St. John's, Newfoundland A1B 3V6. effective form of analgesia. ${ }^{3,4.8-11}$ However, there has been little investigation to determine if this causes any localized adyerse tissue re:iction. Wang ${ }^{1}$ found no adverse tissue reactions in the gross and microscopic studies of the spinal cord of rats with morphine administered directly into the spinal subarachnoid space. Yaksh ${ }^{12}$ found no evidence of pathological change in the spinal cord of cats injected intrathecally with morphine sulfate (Merck) using the light microscope. Similar findings were reported by Aboulish $^{13}$ with intrathecal morphine in monkeys.

We are not aware of any studies to determine if morphine applied to the epidural space would cause any localized tissue reaction, where unlike subarachnoid injection, it is not diluted by CSF. We therefore looked at the local effec:s of epidural morphine in dogs.

\section{Methods}

Experiments were performed on 24 mongrel dogs weighing between 10 and $24 \mathrm{~kg}$ (average weight $14 \mathrm{~kg}$ ). Each dog was anaesthetized with thiopenta] $20 \mathrm{mg} \cdot \mathrm{kg}^{-1}$ and allowed to breathe room air spontaneously. Using sterile technique the epidural space at L7-S1 was located with a 22 gauge, $1 \frac{1}{2}$-inch disposable hypodermic needle, using the technique described by Klide. ${ }^{14}$

The dogs were divided into three groups. Group I was a control group used to ensure accurate injection of the epidural space. The eight dogs of this group were each given one injection of India ink (diluted in $2 \mathrm{cc}$ of normal saline) into the epidural space. These dogs were sacrificed at 4-11 days. Group II consisted of eight dogs which were given $0.07 \mathrm{mg} \cdot \mathrm{kg}^{-1}$ morphine (Allen Hanburys) in $2 \mathrm{cc}$ of normal saline (preservative free) into the epidural space as a single injection. This commercially available morphine contains 0.1 por cent sodium 

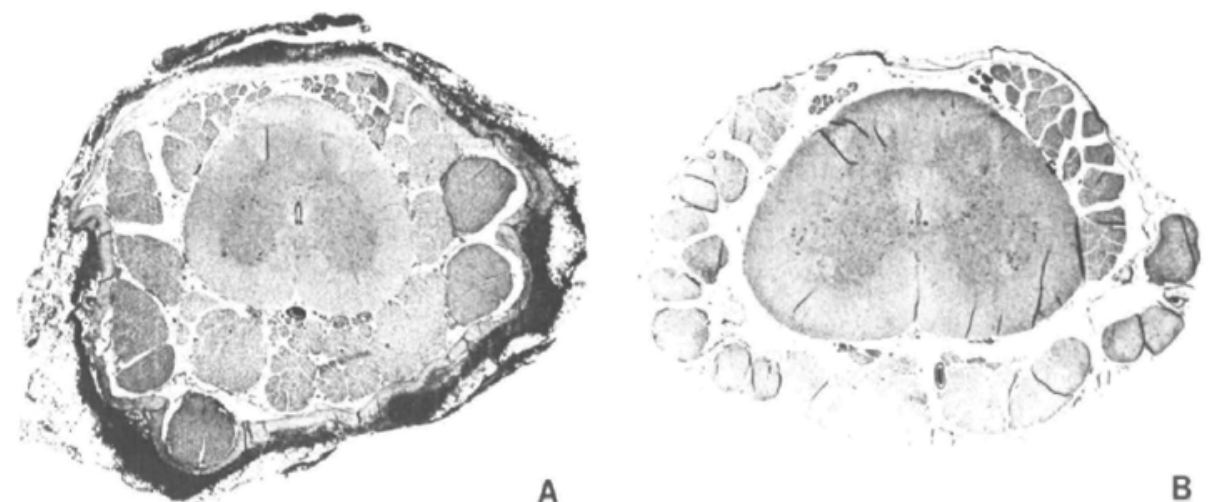

A
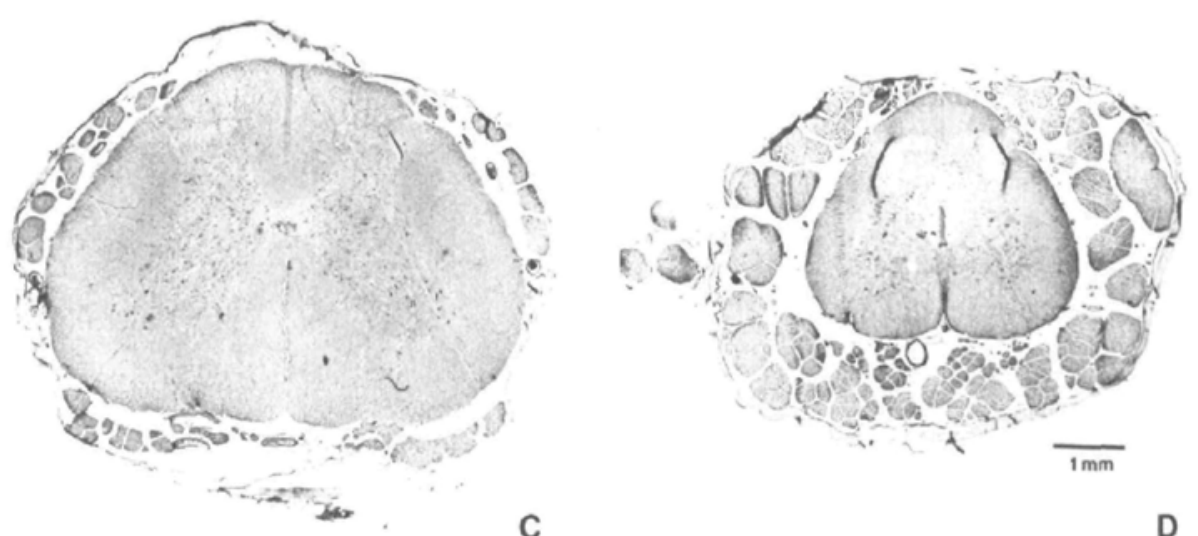

C

D

FIGURE 1 Transverse sections of spinal cord, nerve roots and dura mater at relevant levels. A - Dog one (Group I) showing dense circumferential deposition of India ink pigment in extradural tissue. B - Dog nine (Group II) showing intacl cord and roots with delicate investing dura. $\mathrm{C}$ - Dog 18 (Group III) showing normal cord, roots and dura mater. D - Dog 22 (Group Il) showing intact dura, abundant nerve roots and normal cord. All sections $8 \mu \mathrm{m}$ stained with haemtoxylin and ensin. Scale marker $1 \mathrm{~mm}$.

metabisulfate. Three of these dogs were sacrificed at four days and five dogs at seven days. Group III consisted of eight dogs given the same dosage of morphine as Group II but were sacrificed at 21 days post-injection.

As the early results failed to show any tissue reaction, a "saline only" control group was not included, and eventually turned out to be unnecessary.

The dogs were observed daily by animal laboratory attendants for any abnormal behaviour such as vomiting, change in feeding pattern, bowel and bladder dysfunction, scratching, limping, restless- ness, etc. The attendants were unaware of the group to which each animal belonged.

Immediately after each dog was sacrificed, the epidural space was exposed from T10 to the sacral segments. The epidural space was grossly inspected and the epidural fat, dura, spinal cord and cauda equina were carefully dissected out and placed in buffered ten per cent formalin. Following fixation, representative 3-4 mm thick transversely oriented blocks of lumbar and sacral cord segments were processed through paraffin and $8 \mu \mathrm{m}$ sections stained with haemotoxylin and eosin prepared by standard methods. Serial sections were not used. 


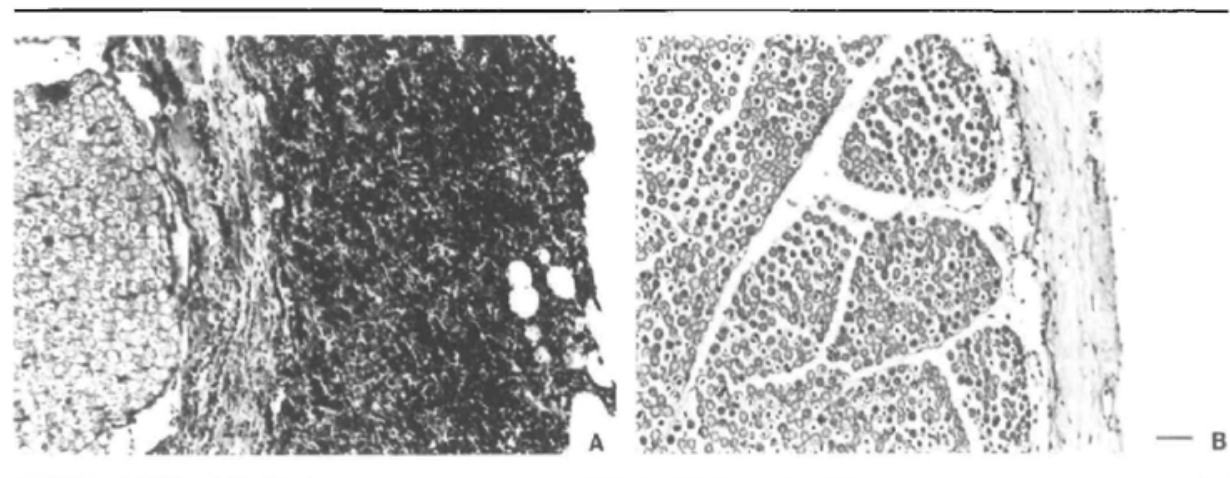

FIGURE 2 A - Dog one (Group I). There is a wide exiradural zone of phagocylosed pigment and inflammatory reaction. Some mononuclear cellular reaction extends into the dura. Nerve root at left margin of micrograph appears normal. B - Dog nine (Group II). Normal dura and nerve root. Both micrographs same magnification. Scale marker $50 \mathrm{~mm}$.

Gross and microscopic examinations were carried out by a neuropathologist who was also unaware of the group to which each animal belonged.

\section{Results}

All 24 dogs tolerated the anaesthetic and epidural procedure well. No dogs showed any apparent abnormality in behaviour or motor function postepidural injection. Post mortem examination of the eight dogs of Group I confirmed localization of the India ink to the epidural space. The volume of $2 \mathrm{cc}$ consistently showed spread of the India ink solution from the sacral segments to the level of T10-T11.

Dogs one through eight (Group I) showed abundant carbon pigment accumulation extradurally around the entire circumference of extradural tissue (Figure 1A). The pigment had elicited a marked inflammatory reaction, predominantly mononuclear (Figure 2A). Occasional small foci of histiocytes were found within the substance of the dura, but otherwise the lesions were entirely extradural. No abnormalities were found in the leptomeninges, nerve roots or spinal cord.

Dogs of Groups II and III showed no gross changes and microscopically there was no cellular or other reaction in the epidural tissue. The dura mater was intact and no abnormality was identified in the leptomeninges, nerve roots or spinal cord (Figures 1B, C, and D; Figure 2B).

\section{Discussion}

India ink was used as a visual marker to delineate the spread of the volume of $2 \mathrm{cc}$ of solution injected into the epidural space of the dogs used in this experiment. Also, it confirmed proper localization of the epidural space. In spite of the intense inflammatory reactions seen microscopically in Group I, no obvious abnormality in general behaviour or motor function was noted.

Our success with India ink identification of the epidural space in the control group makes us confident that the morphine was also injected into the epidural space. Subarachnoid placement of the morphine may have occurred, but with the simplicity of this technique in dogs we feel this is most unlikely.

The dogs of Groups II and III were given epidural morphine (Allen Hanburys) in a dosage of $0.07 \mathrm{mg} \cdot \mathrm{kg}^{-1}$. This dosage was selected because it would be about the equivalent of $5 \mathrm{mg} / 70 \mathrm{~kg}$ which appears to be the average dosage used in clinical setting. ${ }^{8-10,15}$ Our results showed no adverse tissue reaction, grossly or microscopically, from a single injcction of epidural morphine in either the short term of less than one week, or the longer term of three weeks.

Others have used preservative free morphine in their studies ${ }^{9,15,16}$ whereas commercially prepared morphine is more readily available. We used morphine sulfate (Allen Hanburys) which contains $0.1 \%$ sodium metabisulfate as a preservative, yet found no tissue reaction or neurological damage. In clinical practice it is probably preferable to use preservative free morphine to eliminate any pos- 
sible effects of the preservative, but our results would indicate that this view may be unnecessarily overcautious.

This study confirms the lack of local toxicity of epidural morphine. Further studies should be undertaken to investigate any adverse tissue reaction using higher dosage of morphine as well as repeated administration over a prolonged period (as may be used in the relief of chronic pain).

\section{Acknowledgement}

We should like to thank Ms. Ann Morris for her typing of this manuscript.

\section{References}

1 Wang $J K$. Analgesic effect of intrathecally administered morphine Reg Anesth, 1977; 2: 3-8.

2 Wang $J K$, Nauss $L A$, Thomas $J E$. Pain relief by intrathecally applied morphine in man. Anesthesjology 1979; 50: 149-51.

3 Behar $M$, Olshwang D, Magora F, Davidson JT. Epidural morphine in treatment of pain. Lancet 1979; 1; 527-9.

4 Torda TA. Epidural analgesia with morphine a preliminary communication. Anaesth Intensive Care 1979; $7: 367-70$.

5 Calvillo $O$, Henry JL, Neuman RS. Actions of narcotic analgesics and antagonists on spinal units responding to natural stimulation in the cat. Can $\mathbf{J}$ Physiol Pharmacol 1979, 57: 652-3.

6 Dohi S, Toyooka H, Kitahata LM. Effccts of morphine sulfate on dorsal-horn neuronal responses to graded noxious thermal stimulation in the decerebrate cat. Anesthesiology 1979; 51: 408-13.

7 Pert CB, Kuhar MJ, Snyder SH. Opiate receptor: Autoradiographic localization in rat brain. Proceedings of the National Academy of Science, U.S.A. 1976; 73: 3729-33.

8 Bromage PR, Camporesi $E$, Chestnut $D$. Epidural narcotics for post-operative analgesia. Anesth Analg 1980; 59: 473-80.

9 Anderson I. Thompson WR, Varkey GP, Knill RL. Lumbar epidural morphine as an effective analgesic following cholecystectomy. Can Anaesth Soc J 1981; 28: 523-9.

10 Carmichael FJ, Rolbin SH, Hew EM. Epidural morphine for analgesia after Cacsarcan section. Can Anaesth Soc J 1982; 29: 359-63.
11 Bromage PR, Camporesi EM, Durant PAC, Nielsen $C H$. Non-respiratory side effects of epidural morphine. Anesth Analg 1982; 6. : 490-5.

12 Yaksh TL. Reddy SVR. Studies in the primate on the analgesic effects associated with intrathecal actions of opiates, $\alpha$-adrenergic agonists and Baclofen. Anesthesiology 1981; 54: 451-67.

13 Abouleish E, Barmada MA, Nemoto EM, Tung A, Winter $P$. Acute and chronic effects of intrathecal morphine in monkeys. Anesthesiology 1981,55: A153.

14 Soma Lawrence $R$, UMD. Textbook on Veterinary Anesthesia. The Williams \& Wilkins Company, Baltimore, 1971.

15 Holland AJC. Srikantha SK, Tracey JA. Epidural morphine and post-operative pain relief. Can Anaesth Soc J 1981; 28: 453-8.

16 Bromage PR, Camporesi EM, Durant PAC, Nielsen $\mathrm{CH}$. Rostral spread of epidural morphine. Anesthesiology 1982; 56: 431-6.

Résumé

L'emploi de la morphine par voie péridurale semble devoir s'employer de plus en plus fréquemment pour soulager la douleur chronique ou la douleur postopératoire. Cette étude a été entreprise afin de déter. miner la tolérance des tissus à la morphine appliquée dans l'espace péridural du chien. Seize chiens ont reçu $0.07 \mathrm{mg} \cdot \mathrm{kg}^{-1}$ de morphine (Allen Hanburys) diluée dans un volume de $2 \mathrm{ml}$ de soluté salin injecré dans l'espace péridural. Les macroscopies et l'étude microscopique de l'espace péridural, de la duremère et de la moëlle épinière n' ont montré aucun signe de réaction tissulaire. 